\title{
Biometrics, physiology, production, and quality of Cantaloupe melons grown with saline waters under semi-arid conditions
}

\author{
Reivany Eduardo Morais Lima ${ }^{*} \mathbb{D}$, Laíse Ferreira de Araújo' ${ }^{\mathbb{D}}$, \\ Luciana Ferreira de Lima Farias' 10 , Marlos Alves Bezerra² \\ 'Federal University of Ceará, Fortaleza, Brazil \\ ${ }^{2}$ Embrapa Tropical Agroindustry, Fortaleza, Brazil \\ *Corresponding author, e-mail: reivany_eduardo@hotmail.com
}

\begin{abstract}
Brazilian Northeast region emerges as both producer and exporter relevant of cantaloupe melon to several countries; however, this region is vulnerable to salinization problems due to it is inserted in a semi-arid area. This study aimed to evaluate the biometrics, physiological, production and quality of new cantaloupe melon hybrids cultivated with different saline waters under semi-arid conditions. The experiment was conducted using a drip irrigation system in a split-plot randomized design. The plot was different irrigation water electrical conductivity (ECW) levels: $0.5,2.0,3.5$, and $5.0 \mathrm{dS}^{-1}$, while the subplot was two new cantaloupe melon hybrids: Zielo and SV 1044. Plant biometrics (stems and leaves analysis), plant physiology (solutes accumulation and gas exchange in leaves), fruit production (number, weight, and yield), and fruit quality (physical and chemical analysis) were investigated. Stem length, leaf numbers, leaf area, and shoot dry mass decreased when ECW increased from 0.5 to $5.0 \mathrm{dS} \mathrm{m}^{-1}$. Also, there was an increase of $\mathrm{Na}$ and $\mathrm{Cl}$ concentration and reduction of $\mathrm{K}$ concentration in leaves due to ECW increase. Gas exchange reduction, losses in fruit numbers, weight, yield, and in quality were observed with the ECW increase. It is possible to conclude that the ECW increase salinizes the soil and increases $\mathrm{Na}$ and $\mathrm{Cl}$ concentration in plants causing reduction in gas exchange, in growth, and in fruit production and quality. However, the response of cultivated hybrids regarding salinity may be different, as in our study that the Zielo hybrid was less affected by the increase in ECW.
\end{abstract}

Keywords: Cucumis melo L., gas exchange, soluble solids

\section{Introduction}

Melon world production in 2018 was 27.35 million tons becoming one of the most important and widely cultivated crop (FAO, 2018). Brazilian melon production in 2018 was 581 thousand tons in 23 thousand hectares. Brazilian Northeast emerges as the main export region of national fruits and the largest producer of melon. The melon production in this region was 555 thousand tons in $2018,95.5 \%$ of total Brazilian melon production (IBGE, 2018).

The cantaloupe melon has salmon pulp with strong and pleasant aroma (Alves et al., 2000). This fruit is produced worldwide, including in Brazil semi-arid area. Brazil has recently increased cantaloupe melon cultivation area due to high demand in international market. The constant insertion of new melon hybrids has been observed to supply exportation demand, but these new hybrids are being grown without well-defined agronomic knowledge in response to salinity problems presented in producing areas.

Melon production in Brazil semi-arid area has some edaphoclimatic conditions favorable and water sources availability (Gurgel et al., 2010). However, due to this semi-arid area has a high evaporation rate in relation to precipitation, irregular precipitation regimes, underground soils with almost $70 \%$ of crystalline rocks and irrigation waters almost exclusively from artesian reservoirs with high salinity levels (Cosme et al., 2018), it difficult to produce cantaloupe melons with quality.

Salinity is one of abiotic stresses that limits severely crop growth and yield due to water potential reduction, ionic toxicity and nutrient imbalance (Munns \& Tester, 2008). The low water potential can cause morphological adaptations as well as physiological responses. Morphological adaptations in plants include decline in growth rate, and modification of root to shoot ratio for 
desiccation avoidance (Hund et al., 2009). Physiological responses include reduced photosynthetic rate, leaf water potential, and transpiration rate (Morais et al., 2018).

Therefore, this study aimed to evaluate the biometrics, physiological, fruit production and quality characteristics of new cantaloupe melon hybrids cultivated with different saline waters under semi-arid conditions.

\section{Material and Methods}

The field experiment was conducted from November 2015 to January 2016 at Pacajus Experimental Station (Embrapa Agroindústria Tropical), located at $4^{\circ} 10^{\prime}$ $\mathrm{S}, 38^{\circ} 27^{\prime} \mathrm{W}$ at an altitude of $60 \mathrm{~m}$, Ceará State, Brazil. The soil was classified as Typic Quartzipsamment (Quartz Sand) according to Soil Taxonomy from Soil Survey Staff USDA (2014) and its characteristics are reported in Table 1.

Table 1. Soil characteristics from 0 to $0.3 \mathrm{~m}$ depth.

\begin{tabular}{|c|c|c|c|c|c|c|c|c|c|c|}
\hline $\mathrm{pH}$ & $\mathrm{Ca}^{2+}$ & $\mathrm{Mg}^{2+}$ & $\mathrm{Na}^{+}$ & $\mathrm{K}^{+}$ & $\mathrm{Al}^{3+}$ & $\mathrm{H}+\mathrm{Al}$ & SB & CEC & BS & $P$ \\
\hline $\mathrm{H}_{2} \mathrm{O}$ & & & & $\ldots \ldots . . . \mathrm{cm}$ & $\mathrm{rg}^{-1 \ldots \ldots \ldots . . .}$ & $\ldots \ldots \ldots \ldots$ & & & $\%$ & $\mathrm{mg} \mathrm{dm}^{-3}$ \\
\hline 6.3 & 0.40 & 0.40 & 0.07 & 0.13 & 0.10 & 1.20 & 1.00 & 2.20 & 45.00 & 7.20 \\
\hline EC & ESP & $C$ & $N$ & OM & $\mathrm{C} / \mathrm{N}$ & $\mathrm{BD}$ & PD & $\mathrm{FC}$ & WP & $\mathrm{H}_{2} \mathrm{O}$ \\
\hline $\mathrm{dS} \mathrm{m}^{-1}$ & $\%$ & & $\mathrm{~g} \mathrm{Kg}^{-1}$ & & & $\cdots g$ & $-1 \ldots$ & & $\mathrm{g} 100 \mathrm{~g}$ & $\ldots \ldots \ldots \ldots$ \\
\hline 0.29 & 3.00 & 2.28 & 0.19 & 3.93 & 12.00 & 1.76 & 2.63 & 2.98 & 2.00 & 0.98 \\
\hline
\end{tabular}

The climate of area was classified as BSh by Köppen methodology. This climate is tropical with rains in the summer season and dry winter. Maximum and minimum temperatures $\left({ }^{\circ} \mathrm{C}\right)$, and relative humidity (\%) were evaluated through an automated weather station (Figure 1A). Rainfall during the experimental period was $100 \mathrm{~mm}$ (Figure 1B).

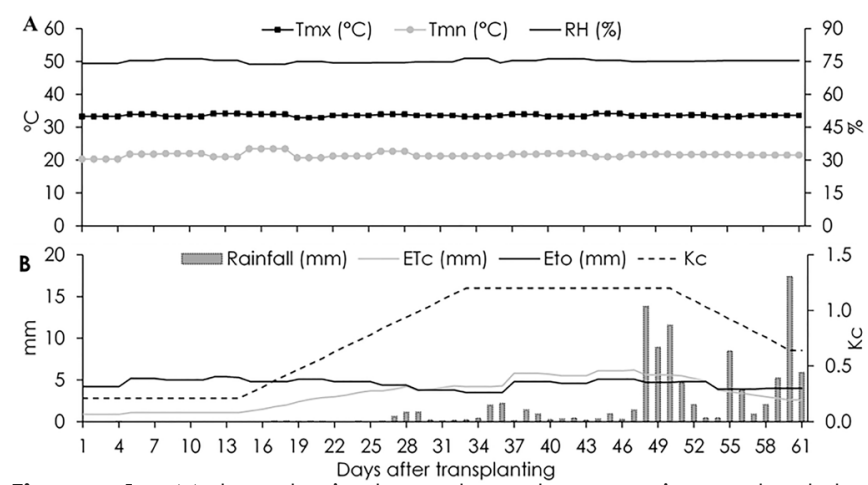

Figure 1. Meteorological and water requirement data. (A): maximum (Tmx) and minimum (Tmn) temperature in ${ }^{\circ} \mathrm{C}$, and relative humidity $(\mathrm{RH})$ in \%. (B): rainfall, reference evapotranspiration (ETo), and crop evapotranspiration (ETC) in $\mathrm{mm}$, and crop coefficient $(\mathrm{KC})$.

Cantaloupe melon seedlings of Zielo and SV 1044 hybrids were obtained from the sowing in 200-cell polypropylene trays containing commercial substrate Forth Soil Conditioner. These seedlings were acclimated in a greenhouse with misting and then transplanted to the experimental area 10 days after sowing when plants had two true leaves.

The soil of experimental area had its base saturation increased by applying dolomitic limestone, raising from $45 \%$ to $80 \%$. After liming, the soil received two light disking, and raising of cultivation beds with 0.8 $\mathrm{m} \mathrm{W} \times 21 \mathrm{~m} \mathrm{~L}$ and two-meter spacing between beds. Drip irrigation system was installed with one irrigation line per bed. These beds were covered with double-face black/ silver plastic mulch, with silver side up. Seedlings were spaced every $0.8 \mathrm{~m}$ in the line.

Plants were fertilized at the base and by fertigation according to the soil analysis obtained from Embrapa's Soil Laboratory (Table 1). The bed base fertilization consisted in application of $120 \mathrm{~kg} \mathrm{ha}^{-1}$ of phosphorus as single superphosphate, $250 \mathrm{~kg} \mathrm{ha}^{-1}$ of frites FTE BR-12 as micronutrients source and $20 \mathrm{~m}^{3} \mathrm{ha}^{-1}$ of bovine fertilizer. Fertigation was applied three times a week, from a nutrient stock prepared in $20 \mathrm{~L}$ container and by a Venturi injector in bypass system. Nutrients used in the fertigation were $120 \mathrm{~kg} \mathrm{ha}^{-1}$ of nitrogen as urea and $120 \mathrm{~kg} \mathrm{ha}^{-1}$ of potassium as white potassium chloride. The fertigation was applied from transplanting to two weeks before fruit harvest, similar to the management adopted by melon producers in the semi-arid area.

Saline waters for irrigation of plants were prepared and stored in different water reservoirs of 5,000 L. They were translocated to plants by a pump of $0.5 \mathrm{CV}$ and PVC lines with $20 \mathrm{~mm}$ diameter for main lines and $16 \mathrm{~mm}$ diameter for irrigation lines. Irrigation lines had water drippers with compensated pressure (2 bar) and flow rate $4.7 \mathrm{~L} \mathrm{~h}^{-1}$, spaced $0.8 \mathrm{~m}$ corresponding one per plant. The water distribution efficiency was indicated by the coefficient of uniformity with a value of $95.5 \%$ from the flow rate data.

Melon plants water requirement was calculated from the "IrrigaMelão" spreadsheet, provided by EMBRAPA (2020). This spreadsheet considers the data collected in an automated weather station to determine the reference evapotranspiration (ET $)_{0}$ (Figure 
1B) according to Penman-Monteith methodology. In addition to $\mathrm{ET}_{0}$, the crop coefficient (KC) (Figure 1B) was considered for the melon crop according to Miranda ef al. (1999). Crop evapotranspiration (ETC) (Figure 1B) was determined by multiplying $\mathrm{ET}_{0}$ by the $\mathrm{Kc}$. The irrigation time in hours was calculated automatically by "IrrigaMelão" spreadsheet (EMBRAPA, 2020).

Irrigation lines were arranged in a completely randomized design in a split-plot treatment design, with eight treatments and four replicates, totaling sixteen plots and thirty-two subplots. The plot, of quantitative order, consisted to different irrigation water electrical conductivity (ECW) levels: $0.5,2.0,3.5$, and $5.0 \mathrm{dS} \mathrm{m}^{-1}$ and each level had four irrigation lines representing four replicates (16 plots). To obtain ECW 2.0, 3.5, and 5.0 dS $\mathrm{m}^{-1}$, the $0.5 \mathrm{dS} \mathrm{m}^{-1}$ water was used with addition of sodium chloride ( $\mathrm{NaCl}$ ), and the values confirmed and monitored by a conductivity meter CD-4301 model from Lutron (Taipei, TW). The subplot, of qualitative order, consisted of two new cantaloupe melon hybrids: Zielo and SV1044.

Plant biometrics and physiology were analyzed in three different growth stages: vegetative stage - VS (19 days after transplanting - DAT), fructification stage - FS (40 DAT) and harvesting stage - HS (61 DAT). Gas exchange and water-use efficiency were analyzed just in the vegetative and harvesting stage. Fruit production and quality variables were analyzed at the end of the crop cycle.

The soil salinity was analyzed from the soil electrical conductivity of saturation extract (ECe) measured by direct contact of conductivity meter WET-1 from Delta-T Devices (Cambridge, UK) with the saturated paste. Soil samples were collected in each plot using a soil collector TS-100 from Sondaterra (São Paulo, BR). These samples were collected $10 \mathrm{~cm}$ distance from plants and from 0 to $0.3 \mathrm{~m}$ depth. The ECe data was used to elaborate ECeECw equation.

The plant biometrics variables analyzed were stem length (SL), stem diameter (SD), leaf numbers (LN), leaf area (LA), and shoot dry mass (SDM). The leaf area was measured using a photoelectric integrator LI-3000 from LICOR (Nebraska, USA).

The plant physiology variables analyzed were gas exchange and solutes accumulation (organic and inorganic solutes) in leaves. Gas exchange were $\mathrm{CO}_{2}$ assimilation rate (A), stomatal conductance (gs), and leaf transpiration (E). Water-use efficiency (WUE) was obtained from the A/E ratio. These analyzes were measured using an infrared gas analyzer - IRGA from LCpro ADC (Hoddesdon, UK) on mature leaves of the primary stem, from 10:00 a.m. to 11:00 a.m.

Solutes accumulation in leaves analyzed were total sugar (TS), potassium (K), sodium (Na), and chloride (CI) concentration in leaves. Leaves were dried and then, an extract of $1 \mathrm{~g}$ of dry leaf to $50 \mathrm{~mL}$ of water was prepared. From this extract, TS was determined by reactions with sulfuric acid and $5 \%$ phenol, both $\mathrm{K}$ and $\mathrm{Na}$ ions were determined by flame photometry, and $\mathrm{Cl}$ ion was determined by molecular absorption spectrophotometry.

Fruit variables were analyzed in production and quality. The fruit production variables analyzed were fruit numbers (FN), fruit weight (FW), and fruit yield (FY). The fruit physical quality variables analyzed were longitudinal (LD) and equatorial diameter (ED) of fruit, thickness (PUT) and firmness (PuF) of pulp, and peel thickness (PeT). The fruit chemical quality analyzed were soluble solids (SS), total sugars (TS), sucrose (SUC), glucose (Glu), and fructose (Fru). Sugars were quantified by high-performance liquid chromatography HPLC RID-10A from Shimadzu (Kyoto, JP), with refractive index detection, using a $\mathrm{Ca}^{2+}$ column from Supelco, with isocratic liquid phase of water and

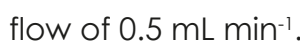

The data analysis of variance (ANAVA) was performed using $F$ test and considering the splitplot treatment design, with irrigation water electrical conductivity (ECW) and cantaloupe melon hybrids ( $\mathrm{Hyb}$ ) as factors. When there was a significant effect on ANAVA, the ECW factor of quantitative order was submitted to linear regression analysis, and the Hyb factor of qualitative order was submitted to Tukey's test at the $5 \%$ significance level. Statistical analysis were carried out using the SISVAR statistical software (Ferreira, 2000).

\section{Results}

The equation between ECe and ECW, at the end of the crop cycle and from 0 to $0.30 \mathrm{~m}$ depth, was linear and increasing, indicating a positive relation between these conductivities (Figure 2).

Evaluating solutes accumulation (organic and inorganic) in leaves, there was interaction between ECW and $\mathrm{Hyb}$ to total sugar (TS) in the fructification stage (Figure $3 \mathrm{~B}$ ) and to sodium ( $\mathrm{Na}$ ) concentration in the harvesting stage (Figure 3K). The ECW factor did not influence $\mathrm{Cl}$ concentration in the fructification stage (Figure $3 \mathrm{~N}$ ) and TS in the harvest stage (Figure $3 \mathrm{C}$ ). Potassium (K) concentration had significant difference to salinity factor in isolation, while to hybrid factor there was no significant difference (Figure 3E, F, G, H).

Analyzing the vegetative stage in Figure 3, while TS and $K$ concentration in leaves responded inversely 


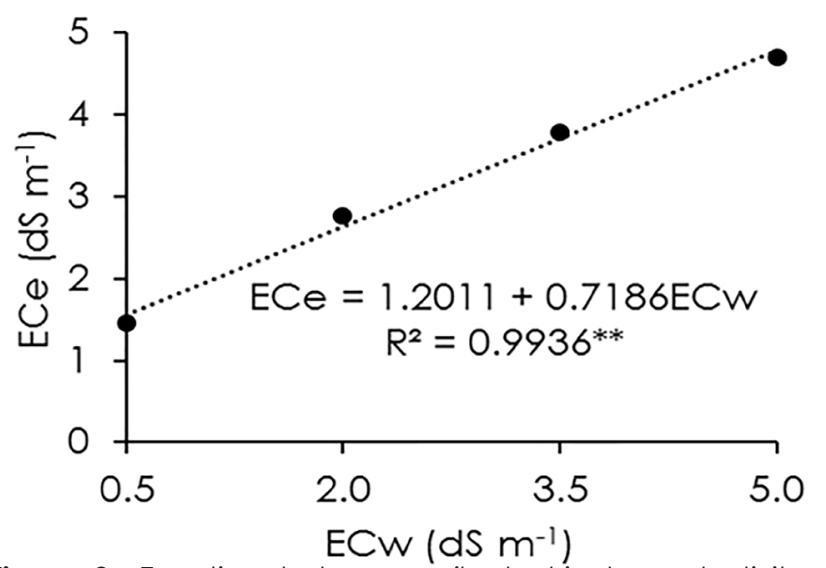

Figure 2. Equation between soil electrical conductivity of the saturation extract (ECe) and irrigation water electrical conductivity (ECW), at the end of the crop cycle. ${ }^{* *}$ Significant at $1 \%$ of probability $(P<0.01)$. proportional to the ECW increase (Figure 3A, E), Na and $\mathrm{Cl}$ concentration responded directly proportionally to the ECW increase (Figure 3l, M). The TS concentration, regardless of hybrid, decreased until the $\mathrm{ECW}=3.17$ dS $\mathrm{m}^{-1}$ and after increased (Figure $3 \mathrm{~A}$ ). In relation to $K$ concentration, the decrease was $45 \%$ (Figure 3E)

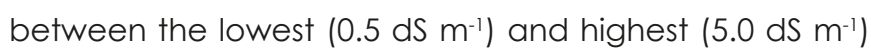
ECW levels analyzed. $\mathrm{Na}$ and $\mathrm{Cl}$ concentration increased by $538 \%$ and $135 \%$, respectively, between the lowest and the highest ECW levels (Figure 3l, M). SV1044 hybrid, regardless of ECW, presented a higher concentration of TS and $\mathrm{Na}$ in leaves when compared to Zielo hybrid (Figure 3D, L).

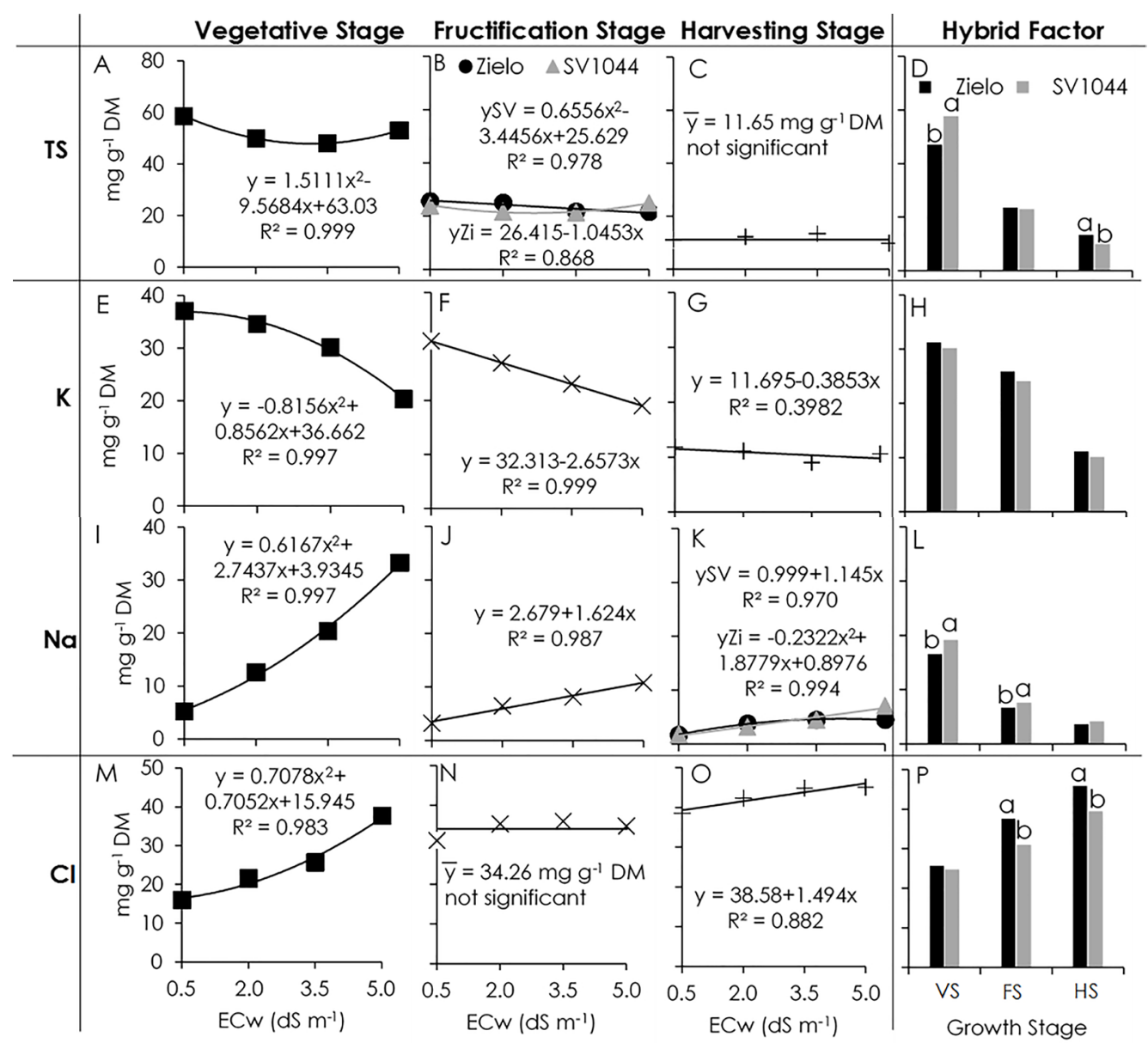

Figure 3. Organic and inorganic solutes concentration in cantaloupe melon leaves. Each graphs row is represented by variables, and each graphs column is represented by growth stage and by hybrid factor in isolation. Total sugars - TS (A, B, C, D), potassium - K (E, F, G, H), sodium - Na (I, J, K, L) and chloride $-\mathrm{Cl}(\mathrm{M}, \mathrm{N}, \mathrm{O}, \mathrm{P})$ concentration. Markers: $(-)$ vegetative stage, $(\mathrm{x})$ fructification stage, and (+) harvest stage to salinity factor in isolation. Valves followed by different lowercase letters are significantly different at $\mathrm{P}<0.05$ in relation to hybrid factor in isolation.

In the fructification stage, TS concentration in SV1044 leaves remained higher than in Zielo from the ECW $=3.96 \mathrm{dS} \mathrm{m}^{-1}$ (Figure 3B). $\mathrm{K}$ and Na concentration presented similar response to the previous stage. $K$ concentration decreased $39 \%$ (Figure $3 \mathrm{~F}$ ) and $\mathrm{Na}$ concentration increased $222 \%$ (Figure 3J). Cl concentration remained constant between saline levels with mean $34.26 \mathrm{mg} \mathrm{g}^{-1}$ of dry mass (DM) (Figure $3 \mathrm{~N}$ ). Sodium concentration remained higher in SV1044 hybrid leaves than in Zielo hybrid (Figure 3L), regardless of ECW analyzed.

In the harvesting stage, there was no significant difference between ECW levels for TS concentration and 
the mean was $11.65 \mathrm{mg} \mathrm{g}^{-1}$ DM (Figure 3C), however the Zielo hybrid leaves presented higher TS concentration in relation to SV1044 (Figure 3D). K concentration decreased $10 \%$ (Figure 3G) and $\mathrm{Cl}$ increased $17 \%$ (Figure 3G) comparing ECW levels from 0.5 to $5.0 \mathrm{dS} \mathrm{m}^{-1}$. Sodium concentration increased similar among hybrids until

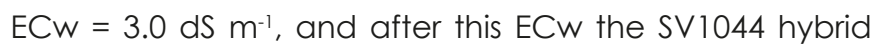
continued to increase while in Zielo stabilized (Figure 3K).

In relation to plant biometrics variables analyzed, there was a higher interaction between factors (ECW $\mathrm{x} \mathrm{Hyb)} \mathrm{in} \mathrm{the} \mathrm{vegetative} \mathrm{stage} \mathrm{than} \mathrm{in} \mathrm{the} \mathrm{other} \mathrm{stages}$
(Figure 4A, I, M, Q). The stem diameter was the only variable that had no significant interaction throughout the melon growing cycle (Figure 4E, F, G).

Analyzing the vegetative stage in the Figure 4, excluding stem diameter (SD) (Figure 4E) in which hybrids were impacted negatively by ECW in the same proportion, for the others biometric variables ECW increase caused higher negative effects in SV1044 hybrid than in Zielo hybrid. The decrease in SV1044 and Zielo hybrid was respectively, $84 \%$ and $71 \%$ in stem length variable (SL) (Figure 4A), $73 \%$ and $62 \%$ in leaf numbers (LN) (Figure

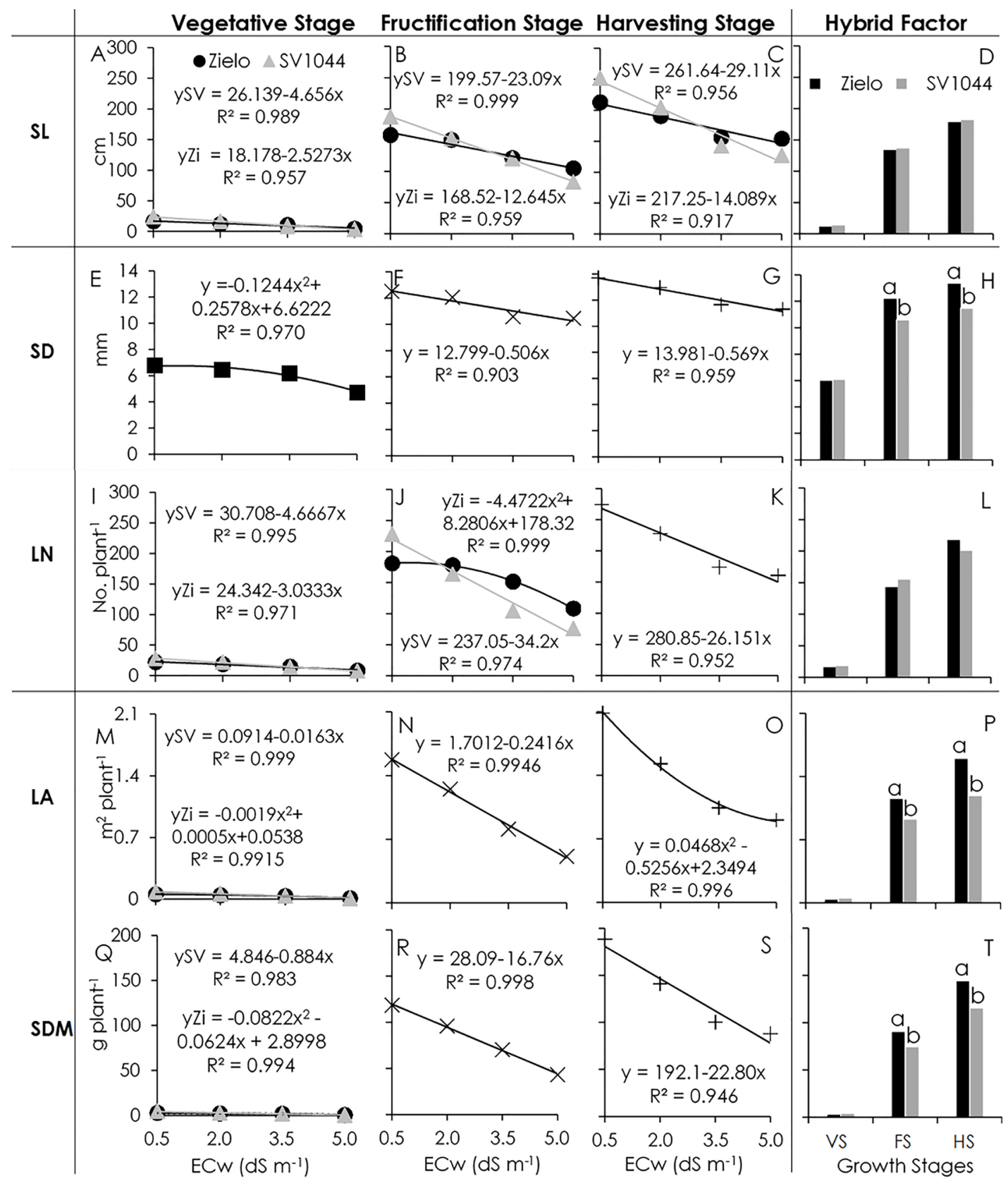

Figure 4. Cantaloupe melon plants biometry. Each graphs row is represented by variables, and each graphs column is represented by growth stage and by hybrid factor in isolation. Stem length - SL (A, B, C, $D)$, stem diameter - SD (E, F, G, H), leaf numbers - LN (I, J, K, L), leaf area - LA (M, N, O, P), and shoot dry mass $(Q, R, S, T)$. Markers: $(\square)$ vegetative stage, $(x)$ fructification stage, and $(+)$ harvest stage to salinity factor in isolation. Values followed by different lowercase letters are significantly different at $P<0.05$ in relation to hybrid factor in isolation. 
4I), $88 \%$ and $83 \%$ in leaf area (LA) (Figure $4 \mathrm{M}$ ), and $89 \%$ and $83 \%$ in shoot dry mass (SDM) (Figure 4Q), comparing values between 0.5 and $5.0 \mathrm{dS} \mathrm{m}^{-1}$.

In the fructification stage, SL and LN variables continued to show interaction between factors (ECW $x$ $\mathrm{Hyb}$ ) (Figure 4B, J), and SV1044 hybrid continued with higher reductions compared to Zielo when the ECW was increased from 0.5 to $5.0 \mathrm{dS} \mathrm{m}^{-1}$. The SL decrease was 56 $\%$ and $34 \%$ (Figure 4B) and the LN decrease was $66 \%$ and $40 \%$ (Figure 4J) for SV1044 and Zielo, respectively. SV 1044 hybrid presented values inferior to Zielo for SL and $\mathrm{LN}$ after $\mathrm{ECW}=2.97$ and $1.68 \mathrm{dS} \mathrm{m}^{-1}$, respectively. There was no interaction for the other variables and the ECW caused a proportional decrease in two hybrids. The ECW increase caused reduction of $16 \%$ in SD (Figure 4F), $67 \%$ in LA (Figure 4N) and $64 \%$ in SDM (Figure 4R). Zielo hybrid had higher values of SD (+15\%), LA (+25\%), and SDM (+22 $\%)$ than SV1044, regardless ECW (Figure 4H, P, T).

At the end of the crop cycle, in the harvesting stage, there was interaction between factors (ECW $x$ Hyb) for SL variable, with the SV1044 hybrid more affected negatively than the Zielo with the ECW increase. The reduction in SL was $11.02 \%$ and $6.15 \%$ per ECW unit increase for SV1044 and Zielo, respectively (Figure 4C). There was no interaction between factors for the other variables, and the reduction was $3.89 \%, 9.16 \%, 12.5 \%$, and $11.8 \%$; for SD, LN, LA, and SDM, respectively (Figure $4 G, K, O, S)$ when increasing one ECW unit. Regardless of ECW level, analyzing the hybrid factor in isolation the Zielo hybrid showed values higher than SV 1044 for SD, LA, and SDM of $16 \%, 35 \%$, and $25 \%$, respectively (Figure $4 \mathrm{H}, \mathrm{P}, \mathrm{T}$ ).

It was observed that the carbon increment in plants was higher from vegetative to fructification stage than from fructification to harvesting stage, regardless ECW level evaluated (Figure 4D, H, L, P, T). It should be emphasized that the time interval between stages was the same, 21 days.

In relation to gas exchange variables, there was no interaction between factors (ECW $x \mathrm{Hyb}$ ) for any stage and there was no significant effect by hybrid factor in isolation. There was significant effect to ECW factor on all variables in harvesting stage; however, in vegetative stage ECW only affected $\mathrm{CO}_{2}$ assimilation rate (Figure 5).

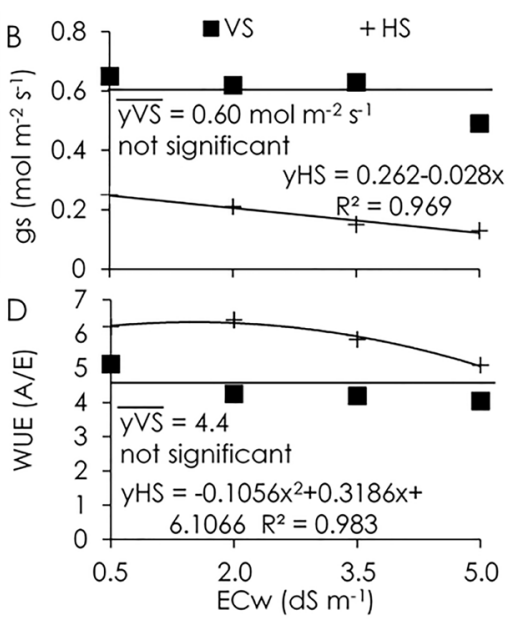
Figure 5. Gas exchange in leaves of cantaloupe melon plants. $\mathrm{CO}_{2}$
assimilation rate-A (A), stomatal conductance-gs (B), leaf transpiration-E (C), and water-use efficiency - WUE (D) to salinity factor in isolation.

Analyzing the vegetative stage in Figure $5, \mathrm{CO}_{2}$ assimilation rate responded inversely proportional to the ECW increase, with $15 \%$ of decrease between the ECW extreme analyzed, the decrease was from 24.1 to $20.5 \mu \mathrm{mol} \mathrm{m} \mathrm{m}^{-2} \mathrm{~s}^{-1}$ (Figure 5A). There was no differentiation between ECW levels for the other gas exchange variables and WUE. Stomatal conductance (gs), leaf transpiration (E), and water-use efficiency (WUE) presented means values of $0.60 \mathrm{~mol} \mathrm{~m}^{-2} \mathrm{~s}^{-1}, 5.13 \mathrm{mmol} \mathrm{m}^{-2} \mathrm{~s}^{-1}$ and $4.4 \mu \mathrm{mol}$ $\mathrm{m}^{-2} \mathrm{~s}^{-1} / \mathrm{mmol} \mathrm{m} \mathrm{m}^{-2} \mathrm{~s}^{-1}$, respectively (Figure $5 B, C, D$ ).

In the harvesting stage, all gas exchange variables and WUE were significantly influenced by the ECW increase (Figure 5A, B, C, D). While the $\mathrm{CO}_{2}$ assimilation rate (A) decrease was $15 \%$ in the vegetative stage, in the harvesting stage it was $41 \%$. The $A$, in the harvesting stage, decreased only after ECW $=1.31 \mathrm{dS}$ $\mathrm{m}^{-1}$ (Figure 5A). The gs, $\mathrm{E}$ and WUE variables, in which remained constant in the vegetative stage, decreased $48 \%, 19 \%$, and $20 \%$, respectively, in the harvesting stage (Figure 5B, C, D) when ECW was increased.

In relation to fruit production of cantaloupe melon, there was interaction between factors (ECW $x$ Hyb) for all variables: fruit numbers, fruit weight and fruit yield (Figure 6).

The fruit numbers (FN) decrease was more significant in SV1044 than in Zielo hybrid, when the ECW 

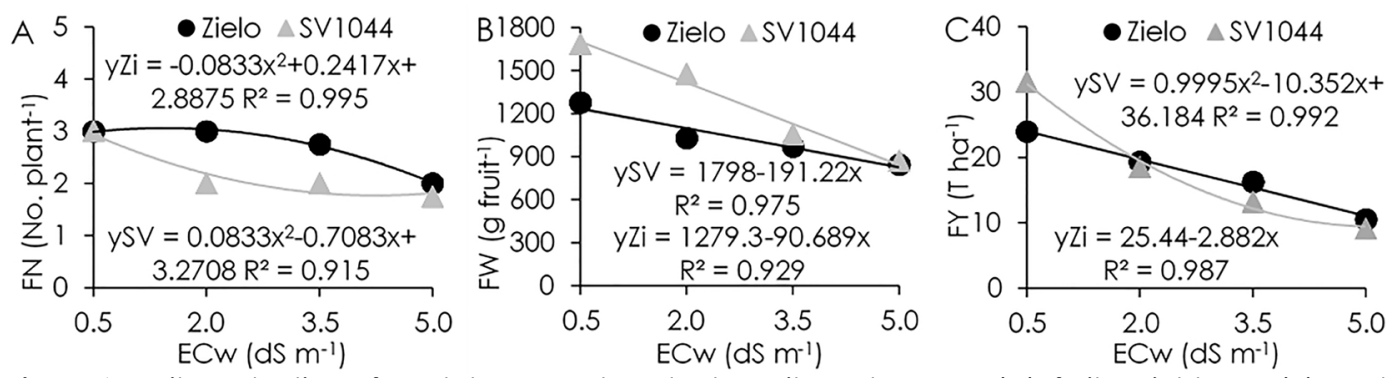

Figure 6. Fruit production of cantaloupe melon plants. Fruit numbers - FN (A), fruit weight - FW (B), and fruit yield - FY (C).

was increased. While the FN decrease started from 1.45 dS $\mathrm{m}^{-1}$ following a gradual decrease in Zielo hybrid,

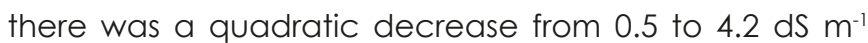
level in SV1044 hybrid. Quadratic equations for FN show coefficient $a<0$ for Zielo and $a>0$ for SV1044 hybrid, inferring a larger negative effect of the ECW in SV1044 than in Zielo hybrid (Figure 6A).

The Zielo hybrid presented lower fruit weight (FW) than SV 1044 when cultivated with fresh water $(E C W=0.5$ dS $\left.\mathrm{m}^{-1}\right), 1300 \mathrm{~g}$ and $1700 \mathrm{~g}$, respectively. SV1044 hybrid had more significant decrease than Zielo hybrid with the ECW increase. This decrease was $815 \mathrm{~g}$ or $48 \%$ for SV 1044 and $434 \mathrm{~g}$ or $34 \%$ for Zielo, between the lowest and the highest ECW levels applied (Figure 6B).

The final fruit yield (FY) of two hybrids presented decreased with the ECW increase. The FY reduction was linear for Zielo hybrid (-56 \%) and quadratic for SV 1044 hybrid (-70.3\%), between the lowest and the highest ECW levels. Thus, Zielo presented a reduction of $12.4 \%$ and SV1044 of $16.1 \%$ for each unit ECW increased. The intercept point between Zielo equation and SV1044 equation indicates that SV 1044 hybrid had less yield than Zielo after ECW $=1.94 \mathrm{dS} \mathrm{m}^{-1}$ (Figure 6C).

Hybrids salinity tolerance was considered from the $20 \%$ yield reduction. Thus, the Zielo hybrid tolerated

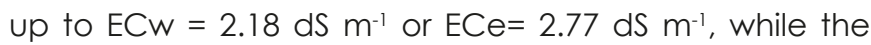
SV 1044 hybrid tolerated up to $\mathrm{ECW}=1.19 \mathrm{dS} \mathrm{m}^{-1}$ or $\mathrm{ECe}=$ $2.06 \mathrm{dS} \mathrm{m}^{-1}$ (Figure 6C).

In relation to fruit physical quality, there was interaction between factors ( $E C W \times \mathrm{Hyb}$ ) for equatorial diameter variable (Figure 7B), but for all others variables each factor, ECW or Hyb, influenced in isolation (Figure 7A, C, D, E, F).
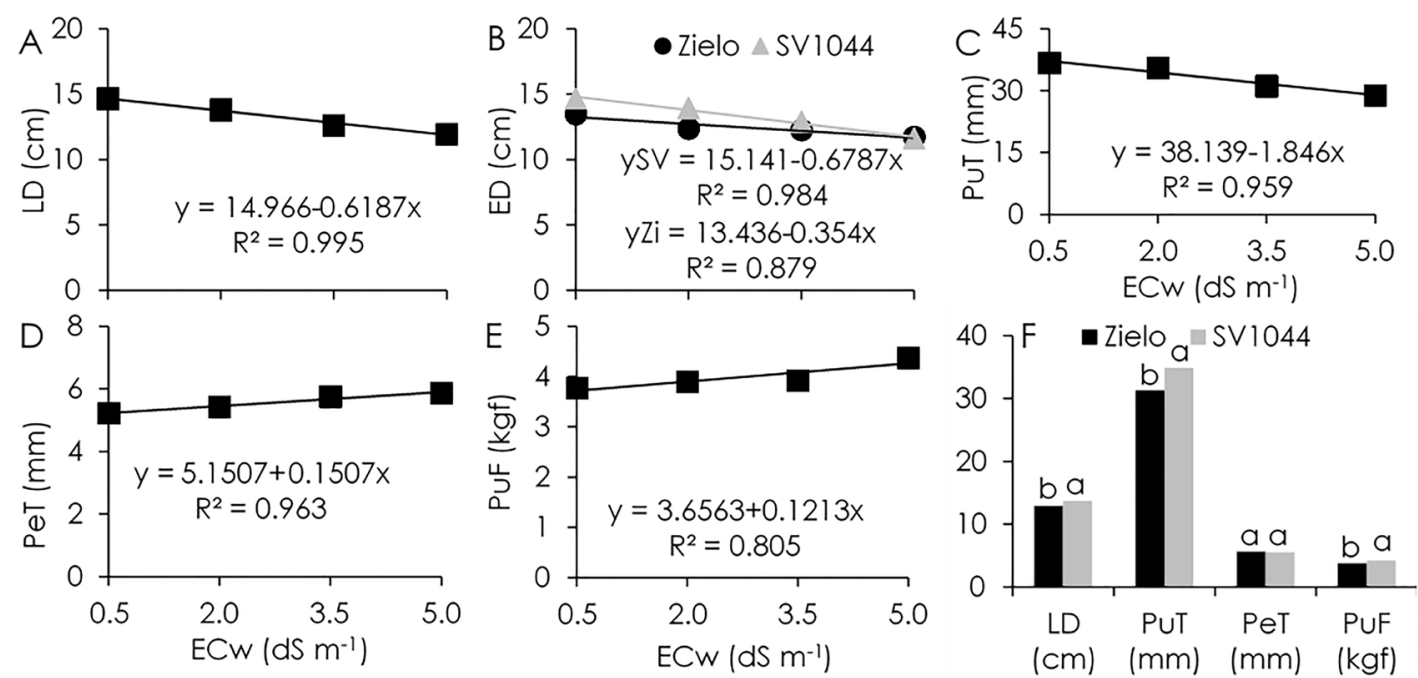

Figure 7. Fruit physical quality of Cantaloupe melon. Longitudinal diameter - LD (A), equatorial diameter - ED (B), pulp thickness - PUT (C), peel thickness - PeT (D), pulp firmness - PuF (E). Variables analyzed separately by hybrid factor (F). Marker ( $\square$ ) to salinity factor in isolation. Values followed by different lowercase letters are significantly different at $\mathrm{P}<0.05$ in relation to hybrid factor in isolation.

The fruit equatorial diameter (ED) decreased 4.5 $\%$ in SV 1044 hybrid and $2.6 \%$ in Zielo, when was increased one ECW unit (Figure 7B). The ECW x Hyb interaction showed once again that SV1044 hybrid was affected more negatively than Zielo.

The ECW factor analyzed in isolation indicated that longitudinal diameter (LD) and pulp thickness (PUT) was inversely proportional to the ECW increase. The LD and PUT reduction was $18.4 \%$ and $21.3 \%$, respectively, when ECW was increased from 0.5 to $5.0 \mathrm{dS} \mathrm{m}^{-1}$ (Figure 7A, C). In contrast, peel thickness (PeT) and pulp firmness (PUF) increased directly proportionally with the ECW 
increase. The PeT increased $13.5 \%$ (Figure 7D) and the PUF increased $16 \%$ (Figure 7E) when ECW was increased from 0.5 to $5.0 \mathrm{dS} \mathrm{m}^{-1}$. The Hyb factor analyzed in isolation indicated that SV 1044 had LD (+6.3\%), PUT (+1 $1.5 \%)$, and PuF (+11.9\%) higher than Zielo hybrid (Figure 7F).

In relation to fruit chemical quality, there was interaction between factors ( $E C W \times \mathrm{Hyb}$ ) for total sugars
(Figure 8B) and sucrose (Figure 8C) concentration. All other variables were influenced in isolation for each factor, ECW or Hyb, (Figure 8). TS and Suc concentration remained constant in Zielo hybrid, however in SV1044 hybrid there was increase of these concentration until $E C W=2.4 \mathrm{dS} \mathrm{m}^{-1}$, after this $E C W$ concentrations decreased (Figure $8 \mathrm{~B}, \mathrm{C}$ ).
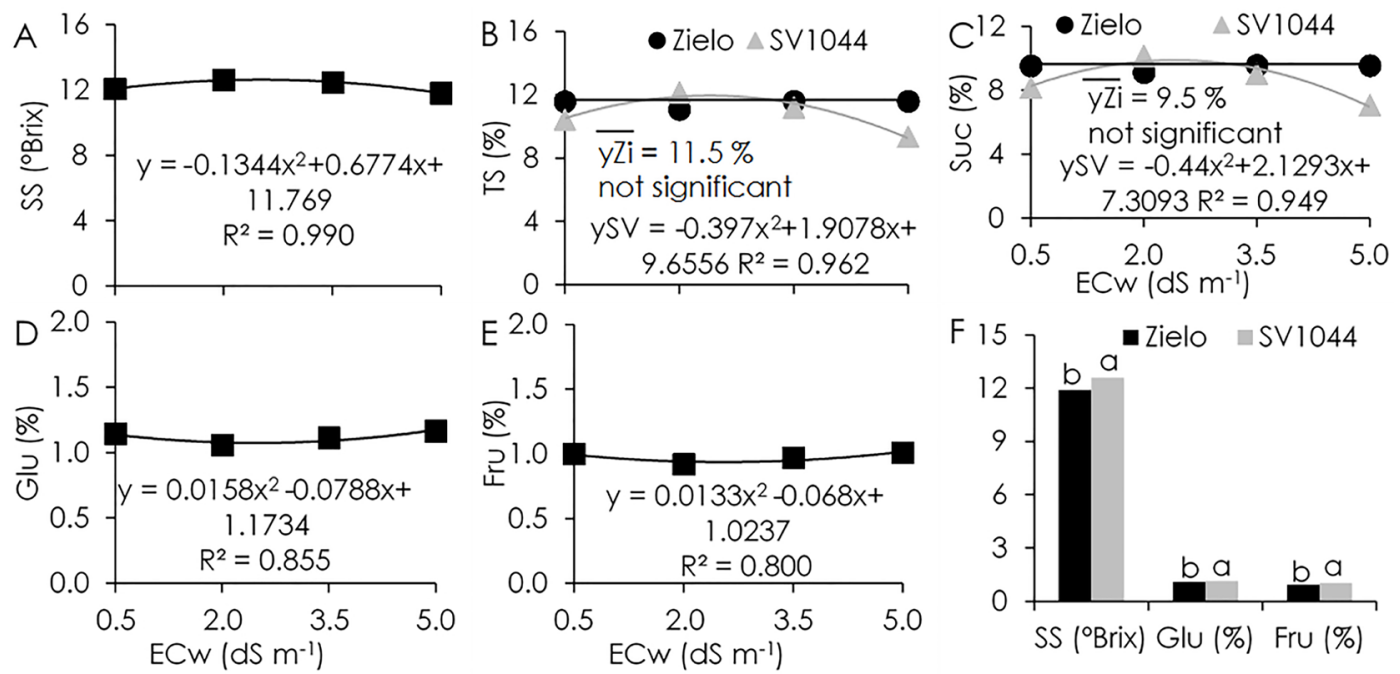

Figure 8. Fruit chemical quality in Cantaloupe melon. Soluble solids - SS (A), total sugars - TS (B), sucrose - Suc (C), glucose - Glu (D), and fructose - Fru(E). Variables analyzed separately by hybrid factor (F). Marker $(-)$ to salinity factor in isolation. Values followed by different lowercase letters are significantly different at $\mathrm{P}<0.05$ in relation to hybrid factor in isolation.

The ECW factor analyzed in isolation indicated that solids soluble (SS), glucose (Glu) and fructose (Fru) concentration present quadratic answer when ECW was increased. The equational answer for SS concentration was inversely proportional to Glu and Fru concentration. While SS increased until ECW $=2.52 \mathrm{dS} \mathrm{m}^{-1}$, with maximum value of $12.6^{\circ}$ Brix (Figure 8A), Glu and Fru concentration decreased until $2.49 \mathrm{dS} \mathrm{m}^{-1}$ and $2.55 \mathrm{dS} \mathrm{m}^{-1}$, respectively (Figure $8 \mathrm{D}, \mathrm{E}$ ). The Hyb factor analyzed in isolation indicated that SV1044 had SS (+5.9\%), Glu (+4.6\%), and Fru (+12\%) higher than Zielo hybrid (Figure $8 \mathrm{~F})$.

\section{Discussion}

The soil salt accumulation proportional to the ECW increase is observed due to the sodium and chloride accumulation in soil from irrigation water. Huang et al. (2012), Selim et al. (2013), Tedeschi et al. (2011) and Tedeschi et al. (2017) found soil electrical conductivity of the saturation extract (ECe) in agreement with this study when the ECW was increased.

The reduction in absolute values of plant biometrics variables are associated to the osmotic, toxic, and nutritional effects. Salts accumulation in leaves, mainly $\mathrm{Na}$ and $\mathrm{Cl}$, affect the $\mathrm{CO}_{2}$ assimilation rate, causing inhibition of leaf expansion, consequently reduction in the area destined to the photosynthetic process, and reduction in the total photoassimilates production (Larcher, 2006). Some studies have shown that plants with high salt tolerance have less growth inhibition (relative growth rate and biomass production) than susceptible plants (Ahmed et al., 2013).

The leaf area reduction is an adaptive mechanism of plants grown under salinity and drought conditions. The transpiration reduction, and consequently reduction in $\mathrm{Na}$ and $\mathrm{Cl}$ uptake, results in a conservation of water in plant tissues (Taiz \& Zeiger, 2013). In this way, inhibition in leaf limb expansion is common characteristic in stressed plants, and in melon this negative effects has been reported (Medeiros et al., 2012). According to our study, Tedeschi et al. (2011) found leaf number reduction when the water salinity was increased. Also, Freitas et al. (2014) and Medeiros et al. (2012) reported decrease in dry mass, $-12 \%$ and $-14 \%$ for each ECW unit increase.

$\mathrm{Na}$ and $\mathrm{Cl}$ concentration in leaves were higher in the vegetative stage than in others stages (FS and HS) when the ECW was increased, and this occurred because plants were transpiring equally regardless of ECW. Plants grown at 0.5 or $5.0 \mathrm{dS} \mathrm{m}^{-1}$, in vegetative stage, transpired equally, but absorbed more $\mathrm{Na}$ and $\mathrm{Cl}$ ions when cultivated with water more saline, explained due to the high salts availability. $\mathrm{Na}$ and $\mathrm{Cl}$ uptake affected negatively $\mathrm{CO}_{2}$ assimilation rate and sugar production, as 
well as caused a lower $\mathrm{K}$ uptake through $\mathrm{Na}$ competition by the same uptake site in roots. Lúcio et al. (2013) and Tedeschi et al. (2017) reported increase in $\mathrm{Na}$ and $\mathrm{Cl}$ concentration in leaves, and Sarabi et al. (2017) reported decrease in $\mathrm{K}$ concentration in leaves when ECW was increased.

At the end of the crop cycle as the exposure of plants to salinity was prolonged, plants had reduction in stomatal conductance and leaf transpiration, possibly to try to absorb less $\mathrm{Na}$ and $\mathrm{Cl}$ ions and keep water inside the cells. The stomatal conductance reduction may have been reinforced by the $\mathrm{K}$ uptake reduction, considering that the stomatal opening is mediated by $\mathrm{K}$ ion.

Lúcio et al. (2013) and Cosme et al. (2017) verified gas exchange reduction when the ECW was increased. This reduction has been attributed to stomatal and nonstomatal causes, associated with salt toxic effects and the low crop capacity to osmotic adjustment, causing physiological disturbance in plants (Larcher, 2006). The gas exchange reduction can be shaped by the stress level to which plants were submitted (Fernandes et al., 2010).

The increase in fruit numbers per plant induces the competition for assimilates among sinks and cause decrease in both individual fruit weight and soluble solids concentration (Valantin et al., 2006). These results were reported in our study when fruit numbers, fruit weight and soluble solids concentration were analyzed for the Zielo and SV1044 hybrids. The smaller solids soluble amount in Zielo than in SV1044 is associated to the higher fruit numbers produced per plant in Zielo than in SV1044.

Corroborating with results observed in our study, Tedeschi et al. (2011) found significant reduction in fruit numbers and in fruit weight when the ECW was increased. Also, Freitas et al. (2014) found decrease of 11 \% in Orange Flesh yield and Melo et al. (2011) found decrease of 16 $\%$ in Galia yield, for each ECw unit increased. Huang et al. (2012), studding melon plants under salinity, reported that the melon tolerance was up to $2.7 \mathrm{dS} \mathrm{m}^{-1}$ and after this value, there was $12.7 \%$ decrease per ECe unit increased. Tedeschi et al. (2011), cultivating melon in the Mediterranean region, observed that the melon salinity tolerated was up to $1.73 \mathrm{dS} \mathrm{m}^{-1}$ and after this ECe value there was $12 \%$ decrease per ECe unit increased.

Discussing about fruit physical quality, the increase of peel thickness occurred probably to keep water inside fruit due to the low uptake water in higher $\mathrm{ECW}$ levels. Another explanation to this thicker peel is that the pulp possibly did not have its ripening complete. Sandri et al. (2007) declare that the thicker peel in fruits occurs to avoid water loss and to increase the fruit useful life, besides giving greater resistance to mechanical shocks; however, it represents loss of comestible part.

Pectic substances that make up the cell walls influence in the pulp firmness. When the fruit mature, these substances are polymerized and occurs the pulp softening (Chen et al., 2015). The ECW increase possibly interfered in pectic substances polymerization increasing pulp firmness in melon fruits of this study. Cosme et al. (2017) reported that increasing ECW levels the pulp firmness increased directly proportional.

Discussing about fruit chemical quality, the positive linearity between soluble solids and ECW increase is associated with the nutrient concentration effect due to the low water supply to the fruit. Huang et al. (2012) and Tedeschi et al. (2011) observed positive linear effect on soluble solids of melon fruits when ECW was increased. European and North American market, to import melon fruits, require at least $10{ }^{\circ}$ Brix of solids soluble at harvest week. All fruits harvested in our study have presented the solids soluble minimum required for export, but other quality characteristics should be taken into account.

Chitarra \& Chitarra (2005) explain that solids soluble concentrations are indirect measure of sugars, because this component represents between $74 \%$ and $87 \%$ of solids soluble in cantaloupe melons. Glucose and fructose contribute almost $100 \%$ of the soluble sugar concentration at the initial stage of fruit development; however, at the final of ripening stage, sucrose reaches $50 \%$ of soluble sugars (Yativ et al., 2010).

\section{Conclusions}

Salts concentration increase in irrigation water, mainly $\mathrm{Na}$ and $\mathrm{Cl}$ ions, cause salts accumulation in soil and in leaves of melon plants, causing reduction in plant growth and consequently reduction in fruit production and quality. These reductions are mediated by specific toxic effect, nutritional imbalance such as reduction of $K$ uptake, as well as reduction in water absorption (osmotic effect) evidenced by the reduction in gas exchange and water-use efficiency.

The Zielo hybrid is tolerant to salinity up to $\mathrm{ECW}=$ $2.18 \mathrm{dS} \mathrm{m}^{-1}$ and the SV 1044 hybrid up to $\mathrm{ECW}=1.19 \mathrm{dS} \mathrm{m}^{-1}$, considering up to $20 \%$ yield reduction. Fruits have quality requirements imposed by the international market up to the salinity levels tolerated. Although fruits have minimum soluble solids concentration required to exportation in all salinity levels, after the levels tolerated there is reduction in fruit size and the fruit pulp is more rigid and has less comestible part. 


\section{Acknowledgements}

This research was funded by the Brazilian Federal Agency for Support and Evaluation of Graduate Education - CAPES DS, the Brazilian Agricultural Research Corporation - EMBRAPA, and the Federal University of Ceará - UFC.

\section{References}

Alves, R.E., Pimentel, C.R., Maia, C.E., Castro, E.B., Viana, F.M., Costa, F.V., Andrade, G.G., Filgueiras, H.A.C. Almeida, J.H.S., Menezes, J.B., Costa, J.G., Pereira, L.S.E. 2000. Manual de melão para exportação. Embrapa, Brasília, Brazil. 51 p.

Ahmed, I.M., Dai, H., Zheng, W., Cao, F., Zhang, G., Sun, D., Wu, F. 2013. Genotypic differences in physiological characteristics in the tolerance to drought and salinity combined stress between Tibetan wild and cultivated barley. Plant Physiology and Biochemistry 63: 49-60.

Chitarra, M.I.F., Chitarra, A.B. 2005. Pós-Colheita de frutos e hortaliças: Fisiologia e manuseio. UFLA, Lavras, Brazil. $783 \mathrm{p}$.

Chen, H., Cao, S., Fang, X., Um, H., Yang, H., Wang, X., XU, Q., Gao, H. 2015. Changes in fruit firmness, cell wall composition and cell wall degrading enzymes in postharvest blueberries during storage. Scientia Horticulturae 188: 44-48.

Cosme, C.R., Dias, N.S., Silva, K.M.P., Silva, C.V.T., Queiroz, I.S.R., Rebouças, T.C., Fernandes, C.S. 2017. Yield and quality of 'gália' melon grown in coconut fiber under different concentrations of macronutrients in the nutrient solution. IDESIA 35: 119-128.

Cosme, C.R., Dias, N.S., Melo, M.R.S., Oliveira, A.M.P., Silva, G.F., Moura, E.S.R. 2018. Avaliação da qualidade das águas de poços em comunidades e assentamentos rurais em Mossoró-RN. Acta lguazu 7: 97-108.

Embrapa. Empresa Brasileira de Pesquisa Agropecuária. 2020. Embrapa Agroindústria Tropical. http://www.cnpat. Il.br/docs/irrigamelao.xls <Access on 22 Apr. 2020>

FAO. Food and Agriculture Organization of the United Nations. 2018. FAOSTAT. http://www.fao.org/faostat/ en/\#data/QC < Access on 28 Aug. 2019>

Fernandes, O.B., Pereira, F.H.F., Andrade Júnior, W.P. Queiroga, R.C.F., Queiroga, F.M. 2010. Effect of calcium nitrate in the reduction of saline stress in melon plant. Caatinga 23: 93-103.

Ferreira, D.F. 2000. Análises estatísticas por meio do Sisvar para Windows versão 4.0. In: $45^{a}$ Reunião Anual da Região Brasileira da Sociedade Internacional de Biometria. UFSCar, São Carlos, Brazil. p. 255-258.

Freitas, L.D.A., Figueiredo, V.B., Porto Filho, F.Q., Costa, J.C.C., Cunha, E. M. 2014. Muskmelon growth and yield under different levels of water salinity and nitrogen. Brazilian Journal of Agricultural and Environmental Engineering 18: 20-26.
Gurgel, M.T., Uyeda, C.A., Gheyi, H.R., Oliveira, F.H.T., Fernandes, P.D.; Silva, F.V. 2010. Growth of melon cultivated under saline stress and potassium doses. Brazilian Journal of Agricultural and Environmental Engineering 14: 3-10.

Huang, C.H., Zong, L., Buonanno, M., Xue, X., Wang, T., Tedeschi, A. 2012. Impact of saline water irrigation on yield and quality of melon (Cucumis melo cv. Huanghemi) in northwest China. European Journal of Agronomy 43: 6876.

Hund, A., Ruta, N., Liedgens. M. 2009. Rooting depth and water use efficiency of tropical maize inbred lines, differing in drought tolerance. Plant and Soil 318: 311-325.

IBGE. Instituto Brasileiro de Geografia e Estatística. 2018. SIDRA. https://sidra.ibge.gov.br/tabela/5457\#resultado <Access on 22 Apr. 2020>

Larcher, W. 2006. Ecofisiologia vegetal. RIMA, São Carlos, Brazil. $531 \mathrm{p}$.

Lúcio, W.S., Lacerda, C.F., Mendes Filho, P.F., Hernandez, F.F.F., Neves, A.L.R., Gomes Filho, E. 2013. Growth and physiological responses of melon plants inoculated with mycorrhizal fungi under salt stress. Semina: Ciências Agrárias 34: 1587-1602.

Medeiros, D.C., Medeiros, J.F., Barbosa, M.A.G., Queiroga, R.C.F., Oliveira, F.A., Freitas, W.E.S. 2012. Growth of "Pele de Sapo" muskmelon under salinity levels and development stage of plant. Brazilian Journal of Agricultural and Environmental Engineering 16: 647-654.

Melo, T.K., Medeiros, J.F., Espínola Sobrinho, J., Figueirêdo, V.B., Pereira, V.C., Campos, M.S. 2011. Evapotranspiration and yield of melon Galia irrigated with water of different salinity and nitrogen fertilization. Brazilian Journal of Agricultural and Environmental Engineering 15: 12351242.

Miranda, F.R., Souza, F., Ribeiro, R.S.F. 1999. Estimativa da evapotranspiração e do coeficiente de cultivo para a cultura do melão plantado na região litorânea do Estado do Ceará. Engenharia Agrícola 18: 63-70.

Morais, P.L.D., Dias, N.S., Oliveira, A.M., Souza Neto, O.N., Sarmento, J.D.A, Gonzaga, M.I.S. 2018. Effects of nutrient solution salinity on the physiological performance of melon cultivated in coconut fiber. Caatinga 31:713-718.

Munns, R., Tester, M. 2008. Mechanisms of salinity tolerance. Annual Review of Plant Biology 59:651-681.

Sarabi, B., Bolandnazar, S., Ghaderi, N., Ghashghaie, J. 2017. Genotypic differences in physiological and biochemical responses to salinity stress in melon (Cucumis melo L.) plants: Prospects for selection of salt tolerant landraces. Plant Physiology and Biochemistry 119: 294311.

Sandri, D., Rinaldi, M., Souza, M.R., Oliveira, H.F.E., Teles, L.M. 2007. Development and quality of melon cultivated in hydroponic with different substrate and bed format. Irriga 12:156-167. 
Selim, T., Bouksila, F., Berndtsson, R., Persson, M. 2013. Soil water and salinity distribution under different treatments of drip irrigation. Soil Science Society of America Journal 77: 1144-1156.

Soil Survey Staff. 2014. Keys to Soil Taxonomy. 12th ed. U. S. Department of Agriculture - USDA, Natural Resources and Conservation Services, Washington DC, USA. 372 p.

Taiz, L., Zeiger, E. 2013. Plant Physiology. 5 ed. Sinaver Associates, Sunderland, UK. 918 p.

Tedeschi, A., Lavini, A., Riccardi, M., Pulvento, C., D'andria, R. 2011 . Melon crops (Cucumis melo L., CV. Tendral) grown in a Mediterranean environment under saline-sodic conditions: part I: Yield and quality. Agricultural Water Management 98: 1329-1338.

Tedeschi, A., Zong, L., Huang, C.H., Vitale, L., Volpe, M.G., Xue, X. 2017. Effect of salinity on growth parameters, soil water potential and ion composition in Cucumis melo cv. Huanghemi in North-Western China. Journal of Agronomy and Crop Science 203:41-55.

Valantin, M.M., Vaissiere, B.E., Gary, C.; Robin, P. 2006. Source-sink balance affects reproductive development and fruit quality in cantaloupe melon (Cucumis melo L.). Journal of Horticultural Science \& Biotechnology 86: 105117.

Yativ, M., Harary, I., Wolf, S. 2010. Sucrose accumulation in watermelon fruits: genetic variation and biochemical analysis. Journal of Plant Physiology 167: 589-596.

Conflict of Interest Statement: The authors declare that the research was conducted in the absence of any commercial or financial relationships that could be construed as a potential conflict of interest.

All the contents of this journal, except where otherwise noted, is licensed under a Creative Commons Attribution License attribuition-type BY. 